Las asociaciones entre individuos se correlacionan

con la diversidad de las conductas en delfines costeros

(Tursiops truncatus) del Sureste del Golfo de México

\title{
Inter-individual association levels correlate to behavioral diversity in coastal bottlenose dolphins (Tursiops truncatus) from the Southwestern Gulf of Mexico
}

\author{
Marah García-Vital ${ }^{1}$, Eduardo Morteo ${ }^{1,2 *}$, Ibiza Martínez-Serrano ${ }^{3}$, Alberto Delgado-Estrella ${ }^{4}$ y Carmen Bazúa-Durán ${ }^{5}$ \\ 'Instituto de Ciencias Marinas y Pesquerías, Universidad Veracruzana. Calle Hidalgo Núm. 617, Col. Río Jamapa, CP 94290, Boca del \\ Río, Veracruz, México. E-mail: maravital@gmail.com (MGV). \\ ${ }^{2}$ Instituto de Investigaciones Biológicas, Universidad Veracruzana. Calle Dr. Luis Castelazo Ayala s/n, km 2.5 Carr. Xalapa-Veracruz, \\ Col. Industrial Ánimas, CP 91190, Xalapa, Veracruz, México. E-mail: eduardo.morteo@gmail.com (EM). \\ ${ }^{3}$ Facultad de Biología, Universidad Veracruzana. Museo de Zoología. Facultad de Biología, Universidad Veracruzana. Circ. Gonzalo \\ Aguirre Beltran s/n Zona Universitaria. CP 91090. Xalapa, Veracruz, México. E-mail: ibimartinez@uv.mx (IMS). \\ ${ }^{4}$ Facultad de Ciencias Naturales, Universidad Autónoma del Carmen. Calle 56 Núm. 4, Esq. Av. Concordia, Col. Benito Juárez, 24180, \\ Cd. del Carmen, Campeche, México. E-mail: delgadoestrella@gmail.com (ADE). \\ ${ }^{5}$ Facultad de Ciencias, Universidad Nacional Autónoma de México. Circuito exterior s/n, Ciudad Universitaria, 04510 México, D. F., \\ México. E-mail: bazua@unam.mx (CBD). \\ ${ }^{*}$ Corresponding author
}

Introduction: Societies in mammal species are influenced by intrinsic and extrinsic factors that affect the temporality of the associations among individuals. Coastal bottlenose dolphins generally live in small fluid aggregations variable in composition, but the nature of their associations is commonly unknown. Our goal was to determine if school size was influenced by dolphins' behavior, and if individuals associated to develop particular activities within the coastal waters of Alvarado, Mexico.

Methods: In total, 80 boat-based surveys were conducted (2002 - 2003 and 2006 - 2009), where group size, behavior, and photo-identification data were collected. From 237 sightings and 2,021 dolphins the mean school size was 8.5 animals (s. d. = 8.6), but individuals and pairs were observed more frequently (33\%).

Results: Temporal differences in school sizes and behavior conveyed with habitat seasonality $(P<0.05)$, but were inconsistent across years; thus short-term factors such as marine traffic and fisheries intensity were deemed important. Dolphins were commonly feeding ( $29 \%$ ) corresponding to groups of 4 - 6 animals, whereas solitary individuals typically showed evasion $(P<0.01)$.

Discussion and Conclusions: Association coefficients computed for 89 of the 232 identifiable dolphins proved not random only in $6 \%$ of the 3,915 combinations $(P<0.05)$, and these coefficients were positively correlated to the diversity of activities developed by each dyad $(P<0.01)$, thus the nature of their associations in most cases $(93 \%)$ became richer with time. The community is likely formed by very small units that frequently exchange members; this may be due to large food availability and low predator abundance in the area, but also to avoid detection and threats posed by local artisanal fisheries.

Key words: Avoidance; behavior; group size; membership; socialization; fisheries. 


\section{Introduction}

Societies in mammal species are dynamic and complex (e. g. carnivores, primates, cetaceans), in which many of their members may interact and associate with other known or unknown individuals, forming distinctive assemblages (Goodall 1986). The structure of such social units is often affected by age, sex, reproductive status, hierarchy and kin selection (Beddia 2007); all these aspects may modify the behavior of individuals (Bräger 1993) and determine how the animals spend their time in certain areas, thus producing different patterns of residency, seasonality or migration that change their associations and the social structure of the population (Scott and Chivers 1990).

Dolphin societies or communities (sensu Wells et al. 1987) are generally composed by individuals that inhabit the same general area and have frequent interactions with each other (Goodall 1986); thus marine mammalogists often use this term to describe assemblages of individuals of the same species, instead of assemblages of different species as referred in texts of classic ecological theory (Roughgarden 1989). Such aggregations are loose and fluent, where individual and genetic exchange may occur over time within the limits of the community (Wells et al. 1987).

Individual interactions are influenced by intrinsic factors such as the presence of recurrent associations (Connor et al. 2001), which in turn may be determined by extrinsic factors such as habitat variability (e. g. food abundance and availability, as well as natural and human-related threats (Lusseau et al. 2006; Quintana-Rizo 2006; Morteo and Hernández 2007; Morteo et al. 2012). Social and ecological pressures may dictate the temporality of the associations at different scales (McDonald and Carr 1989; Quintana-Rizzo 2006; Morteo et al. 2014). For instance, some species are known to maintain strong permanent and even multilevel associations such as killer whales (Orcinus orca) and sperm whales (Physeter microcephalus; Bräger et al. 1994; Whitehead et al. 2012), whereas other like the spinner dolphin (Stenella longirostris) are very loose (Chilvers and Corkeron 2002).

The social structure of coastal bottlenose dolphins (Tursiops truncatus) has been characterized as fission-fusion, involving small groups that constantly exchange individuals forming a wide range of social bonds (Goodall 1986; Wells et al. 1987; Connor et al. 1992). Several communities of the coastal form of this species are known to present segregation related to sex, age and reproductive status, thus the nature of their associations is highly variable (Wells et al. 1987; Wells 1991; Connor et al. 1992; Smolker et al. 1992; Connor et al. 2000; Quintana-Rizzo and Wells 2001; Morteo et al. 2014).

Living in social groups facilitates feeding, protecting against harassment, predation, enhances reproductive output, and promotes communication and learning (Bräger et al. 1994). Individuals may join or leave a group in response to the gains or losses of participating with the partners involved within a given social unit (Wrangham et al. 1993). Thus recording the activities of animal groups is useful to establish behavioral patterns in a specific habitat (Bräger 1993; Steiner 2011), but also to determine the current state of individuals within a community (Beddia 2007).

Coastal bottlenose dolphins inhabiting the waters off Alvarado in the state of Veracruz have been studied intermittently since 1993 (García 1995) and reliable data on individual identities has been collected since 2002 (Del Castillo 2010; Morteo et al. 2014). Many of these dolphins are known to associate and develop a range of activities, but little is known on how these animals interact and form groups, and if they do it with different purposes (Morteo 2011; García-Vital 2012). The goal of this study is to establish if school size is determined by the activities of the dolphins, and if individuals associate with specific partners to develop particular sets of activities. 


\section{Materials and methods}

Study area. The Alvarado region is a shallow ( $<20 \mathrm{~m}$ depth) open coastal habitat in the southwestern Gulf of Mexico, strongly influenced by river discharges (Figure 1); habitat modification is the major threat to the area (Del Castillo 2010; Morteo 2011; García-Vital 2012). It is the third largest coastal lagoon system in Mexico, and according to the National Institute of Fisheries (INAPESCA), it's the most important shrimp fishing ground in the state of Veracruz, which takes place year-around depending on weather and market demands. Sea surface temperature ranges from 20 to $32.5^{\circ} \mathrm{C}$, with an annual average of $27^{\circ} \mathrm{C}$. The regional climate is tropical with three seasons: a Dry season (March-June) with a significant reduction in average precipitation; a Rainy season (July-October), in which runoff from rivers into the adjacent lagoon and mangrove forest causes high organic matter and nutrient input into coastal waters; and a Windy season (November-February, locally known as "Nortes"), featuring strong winds (up to $80 \mathrm{~km} \mathrm{~h}^{-1}$ ) associated with the incursion of northern cold fronts, which may last several days. Fisheries are relevant to coastal dolphin populations due to the frequent adverse interactions between dolphins and local fisheries, causing incidental mortality of dolphins in nets (Morteo 2011; Morteo et al. 2012). Around 2000 fishermen were active in the area, most of which (75 $85 \%$ ) operate in the lagoon and the rest operate in open waters. No official data is available on marine traffic or fishing effort and port facilities are dedicated to fishing, therefore there is no alternative commercial seagoing activity.

Surveys. Photographic line-transect surveys were conducted at least twice per month from October 2002 to September 2003 and from May 2006 to April 2009. The extent of the surveyed area was dependent on the duration of daily operations, and intended to maximize the chance

Figure 1. Study area and survey trajectories (bold lines). Dashed lines show depth contours every $5 \mathrm{~m}$.

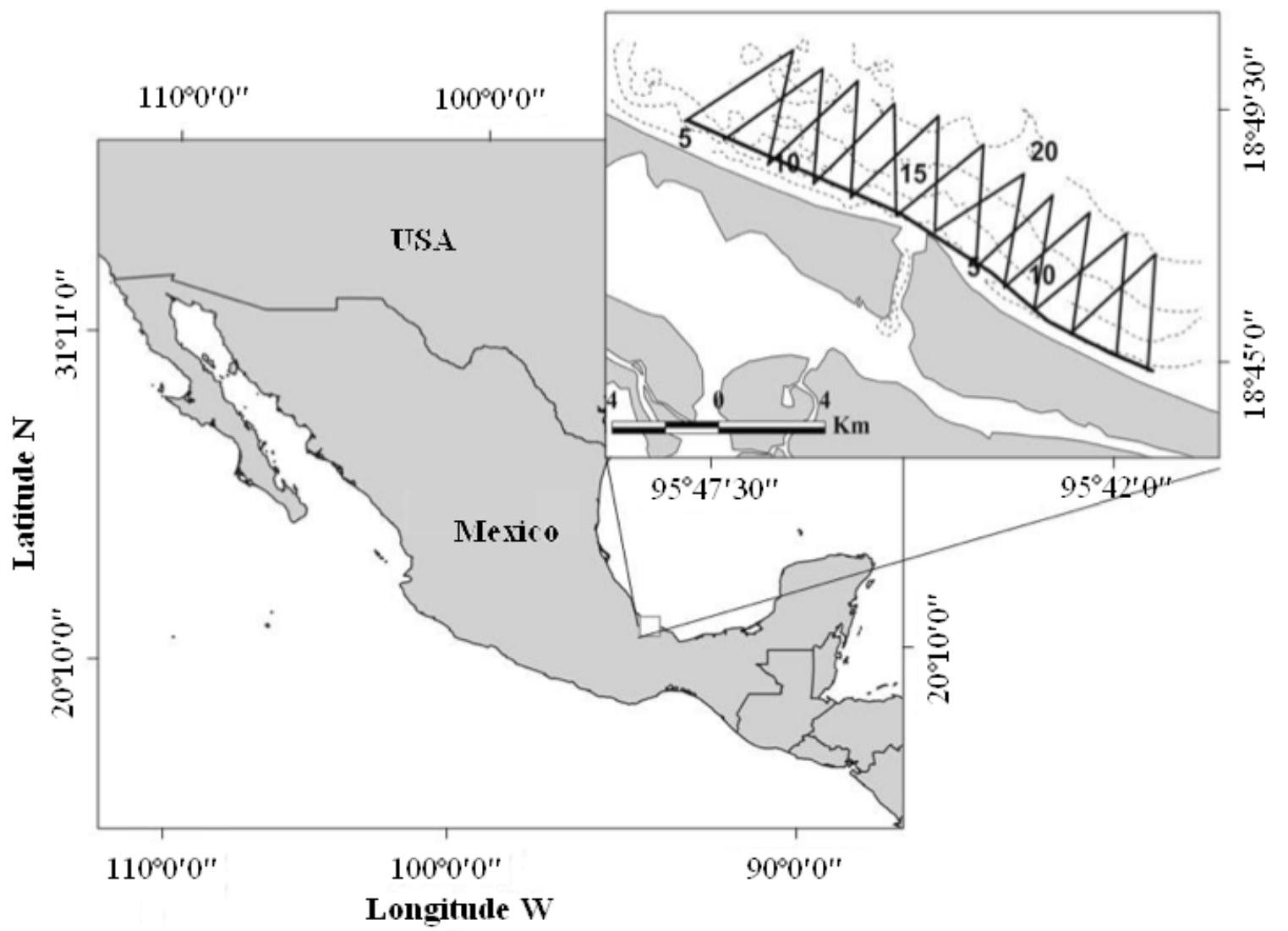


of encountering coastal dolphins, based on their habitat preferences (Fazioli et al. 2006). Surveys were carried out at constant speed $\left(15-18 \mathrm{~km} \mathrm{~h}^{-1}\right)$ always in low swell conditions (sea state Beaufort $\leq 3$, where wind speed $<15 \mathrm{~km} \mathrm{~h}^{-1}$ ) on board of a $7 \mathrm{~m}$ outboard fiberglass skiff (40 / 60 $\mathrm{hp}$ ). When dolphins were sighted, the survey was paused to allow habituation (10 min) while their location was recorded using a GPS (Garmin eTrex Legend). Dolphins were then observed until their behavior was determined ad libitum (Altmann 1974) and classified into one of the most commonly used categories which were: 1) Feeding, 2) Socializing, 3) Traveling, 4) Avoiding, 5) Resting, and 6) Undetermined, following the literature (see Shane 1990; Bräger 1993; Chilvers and Corkeron 2002; Constantine et al. 2004; Steiner 2011). Subsequently, the group was approached with caution to avoid disturbing them, at the time that group size was estimated; we used an inclusive definition of group, consisting in all dolphins observed in apparent association, moving in the same direction and often, but not always, engaged in the same activity (Bräger et al. 1994); however, some groups included only one dolphin (Fazioli et al. 2006). Dolphins were followed until all dorsal fins were photographed or until they were lost from sight; we used SLR cameras, both analogical (Canon EOS Rebel 2000 with film Kodak Tri-X-pan ISO 400) and digital (Canon Rebel XT and Nikon D50) with 70 - 300 mm lenses. The survey was then resumed and the search proceeded until the study area was completed.

Group size and behavior. All sighting records from 2002 - 2003 and 2006 - 2009 (2002 - 2009 henceforth) were arranged into histograms to determine the most common types of aggregations and behaviors within the area. Average group size was computed for comparison, whereas differences among months, seasons and years were examined for both group size and behavior frequencies using non-parametric tests $(a=0.05)$. Also, a correspondence analysis was performed to explore the relation between group size and the behavioral categories using Statistica 7.0.

Photographic identification. Individual dolphins were identified by the marking patterns on their dorsal fins (Würsig and Jefferson 1990; Morteo 2011). Markings such as tooth rakes, scars, pigmentation marks, superficial wounds, and epiphytic organisms are temporary, thus these were considered unidentifiable and were excluded. Only dolphins with permanent and conspicuous markings were included, only if they were sighted in five or more survey days (Bräger et al. 1994; Félix 1997; Bejder et al. 1998; Rogers et al. 2004); thus, analyses were performed only for dolphins with a certain degree of residency.

Association patterns and behavioral diversity. Photographic data were also used to compute half-weight (i. e. controlled for sighting frequencies) coefficients of association (COA) for each dyad (pair of individuals; e. g. Smolker et al. 1992; Bräger et al. 1994; Félix 1997; Quintana-Rizzo and Wells 2001; Rogers et al. 2004) using SOCPROG 2.4 (Whitehead 2009). COA values range from zero for dolphins that are never seen together, to one for a pair that is always seen together. COA values were categorized as infrequent $(0.0-0.2)$, casual $(0.2-0.4)$, fair, $(0.4-0.6)$, moderate $(0.6$ - 0.8) or strong (0.8 - 1.0; Smolker et al. 1992; Quintana-Rizzo and Wells 2001). Also, to prevent the occurrence of artificial dyads (i. e. individuals photographed together by chance due to our inclusive definition of group), a preferred/avoided partner assessment was developed through a permutation test (Smolker et al. 1992; Bejder et al. 1998; Gero et al. 2005).

The recorded behaviors were used to calculate a measure of diversity for the activities developed by all paired individuals; therefore, the Shannon-Wiener index was used as a proxy for each dyad; the latter was standardized to meet the COA range values $(0-1)$ and renamed as activity diversity index (ADI). Since dolphin sightings containing more than two individuals would use the same behavioral records for the computation of the ADI in their respective dyads, the result would overestimate the contribution of each pair to the index (Hurlbert 1984); therefore, we randomly removed photographic data from individual dolphins until the statistical distribution of the ADI and the COA values stabilized. We then computed new COA and ADI in order to reduce 
the bias from the pooling fallacy (Machlis et al. 1985). Finally, the resulting COA and ADI matrices were analyzed using a Mantel's one tailed test, which measures the correlation between the values within two symmetrical matrices containing the data from all the possible combinations between individuals, throughout a randomization process $(a=0.05$, Spearman correlation, Monte Carlo method and 10,000 permutations).

\section{Results}

Survey effort and group size. The Alvarado area was sampled on 80 photographic surveys accounting for 237 groups and 2,021 sighted dolphins. Average school size was 8.5 (s. d. = 8.6) but single animals (16.7\%) and pairs (16.3\%) accounted for almost a third of the recorded sightings (Figure 2). Groups were significantly larger in specific months (June and April, $P<0.01$, Table 1), seasons (dry, $P<0.01$, Table 1$)$ and years $(2002-3,2007-8, P<0.01$, Table 1$)$ across the study period.

Table 1. Group size (numbers) and prevalent behaviors of bottlenose dolphins observed within different periods in the study area $\left(n=237,{ }^{*}=P<0.01\right)$.

\begin{tabular}{lccc}
\multicolumn{1}{c}{ Period } & Mean (s.d.) & Group size & Behavior \\
\hline $2002-2003$ & $10.3(1.1)^{*}$ & Apr $^{*}$, Jun$^{*}$ & Feeding $^{*}$, Resting* \\
$2006-2007$ & $7.6(0.6)$ & - & Feeding* \\
$2007-2008$ & $9.6(0.9)^{*}$ & Sep* $^{*}$ & Socializing* \\
$2008-2009$ & $8.2(0.7)$ & Nov $^{*}$, Feb $^{*}$ & - \\
Rainy & $8.4(0.7)$ & Sep* $^{*}$ & Feeding* \\
Windy & $7.6(0.8)$ & Nov*, Feb* $^{*}$ & - \\
Dry & $9.3(0.7)^{*}$ & Apr $^{*}$, Jun $^{*}$ & - \\
\hline
\end{tabular}

Behavior and group size. Behavioral records existed for 220 of the 237 sightings, where feeding was the most common activity in the area $\left(29 \%, X^{2}=15.22, P<0.05\right)$, but this was true only for years 2002-2003 and 2006-2007 ( $P<0.05$, Table 1). Seasonal differences were observed only for the rainy months, were feeding was also significantly more frequent $\left(X^{2}=23.05, P<0.05\right)$.

Group size was arranged into class intervals according to its frequency in order to homogenize sample sizes (Figure 2). Correspondence between group size and behavior was significant within the studied period $\left(X^{2}=69.47, P<0.01\right)$ where the first two dimensions explained $76.1 \%$ of the

Figure 2. Group size proportion for bottlenose dolphins sighted in the study area during $2002-2009$ ( $n=237)$.

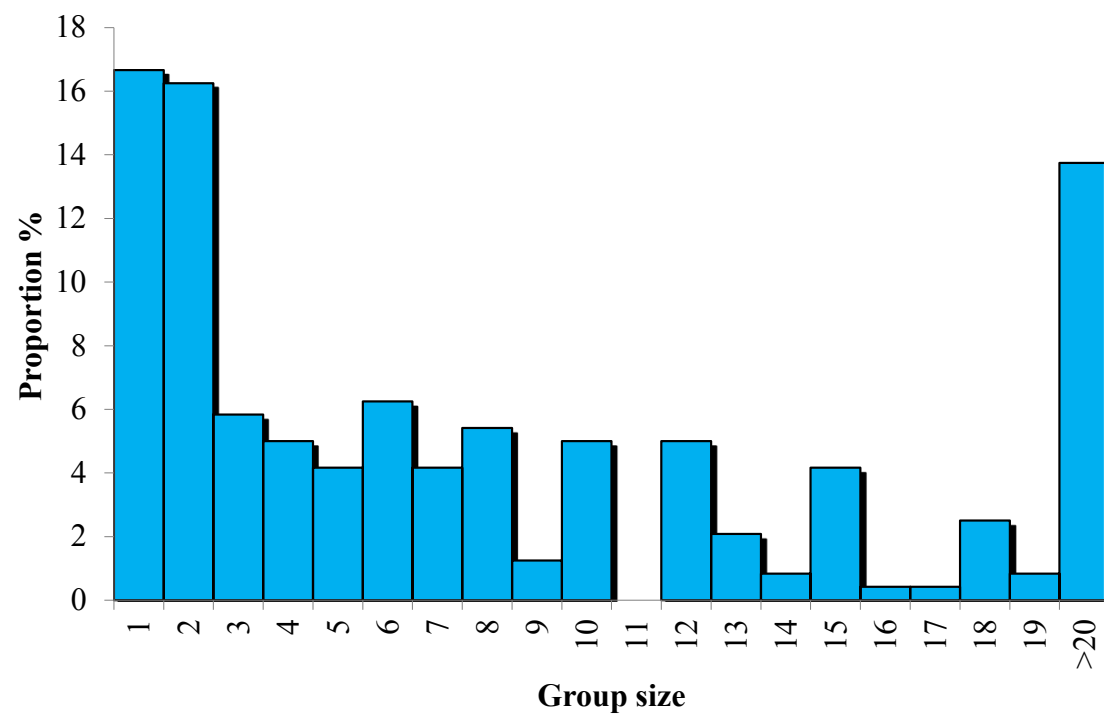


variance, and only three behavioral categories were associated to group size: dolphin pairs were mostly resting, whereas feeding aggregations were formed of four to six dolphins, and solitary individuals commonly showed evasion (Figure 3).

Association patterns and behavioral diversity. A total of 232 different dolphins were individually identified, but only 89 were sighted at least five times, and only one was recognized on up to 47 occasions. Association values (COA) changed annually (Figure 4), as the composition of the members within the community was very fluid, and only eight individuals were consistently identified over the years. The combination of these 89 individuals resulted in 3,915 possible dyads and $67.2 \%$ of these were photographed at least once; however, the permutation test showed that only 237 pairs $(6 \%)$ were non-random $(P<0.05)$. From the latter, visual inspection of COA values showed that $11 \%$ avoided each other $(0.0-0.2)$, or met infrequently $(0.2-0.4)$, whereas $68 \%$ were moderately associated $(0.4-0.6)$, and the remaining were either close $(7 \% ; 0.6-0.8)$ or very close (0.8 - 1.0) partners (3\%; Figure 5).

The diversity of activities (ADI) for each dyad showed a wide range of values, and its statistical distribution stabilized upon the random elimination of half of the records from the 237 significant pairs (Figure 5). Only $5 \%$ of the dyads had very high diversity $(0.8-1.0), 9 \%$ had high diversity (0.6 - 0.8), $31 \%$ were fairly diverse $(0.4-0.6), 34 \%$ developed a low diversity of activities $(0.2-0.4)$, and $20.3 \%$ of the dyads were selective $(0.0-0.2$, all null values corresponded to avoided partners, i. e. $\mathrm{COA}=0$; Figure 5).

The Mantel's test showed significant correlation between the COA and ADI matrices $\left(r_{(A B)}=\right.$ $0.98, P<0.01)$, thus the diversity of activities developed by each dyad increased significantly with their level of associations; however, a few instances deviated significantly from this pattern. For instance, $7.2 \%$ of the dyads had moderate to very high associations but developed a low or very low diversity of activities (low-right corner in Figure 6), specifically feeding and socializing.

Figure 3. Correspondence analysis between activities and group class (size) for bottlenose dolphins sighted in the study area during $2002-2009 . \mathrm{F}=$ Feeding; $\mathrm{T}=$ Travel; $\mathrm{E}=$ Evasion $\mathrm{S}=$ Social; $\mathrm{R}=$ Rest $(n=220)$.

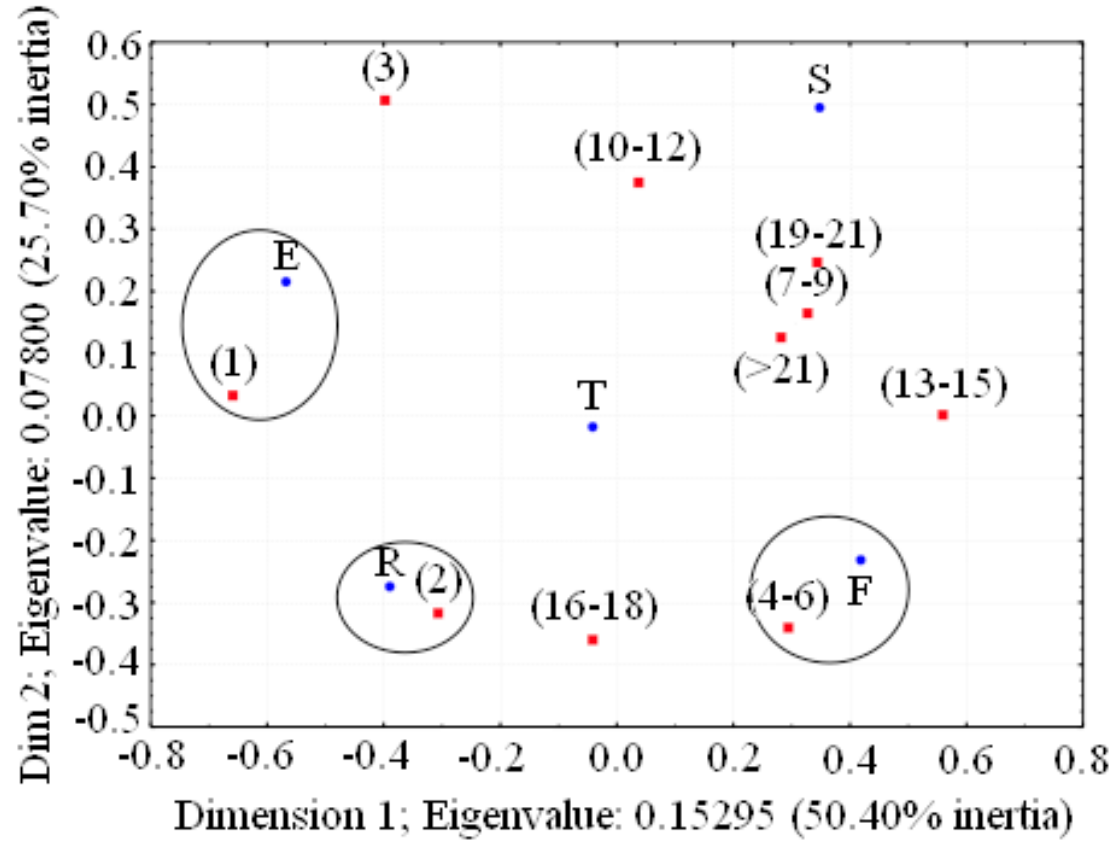


Figure 4. Annual sociograms for dolphins identified at least 5 times in the study area during $2002-2009$. Line thickness shows the values for coefficients of association between dyads. Individuals with $\operatorname{COA}<0.6$ were removed $(n=27, n=89)$, and also diagrams and line thickness were scaled differently to fit the figure.
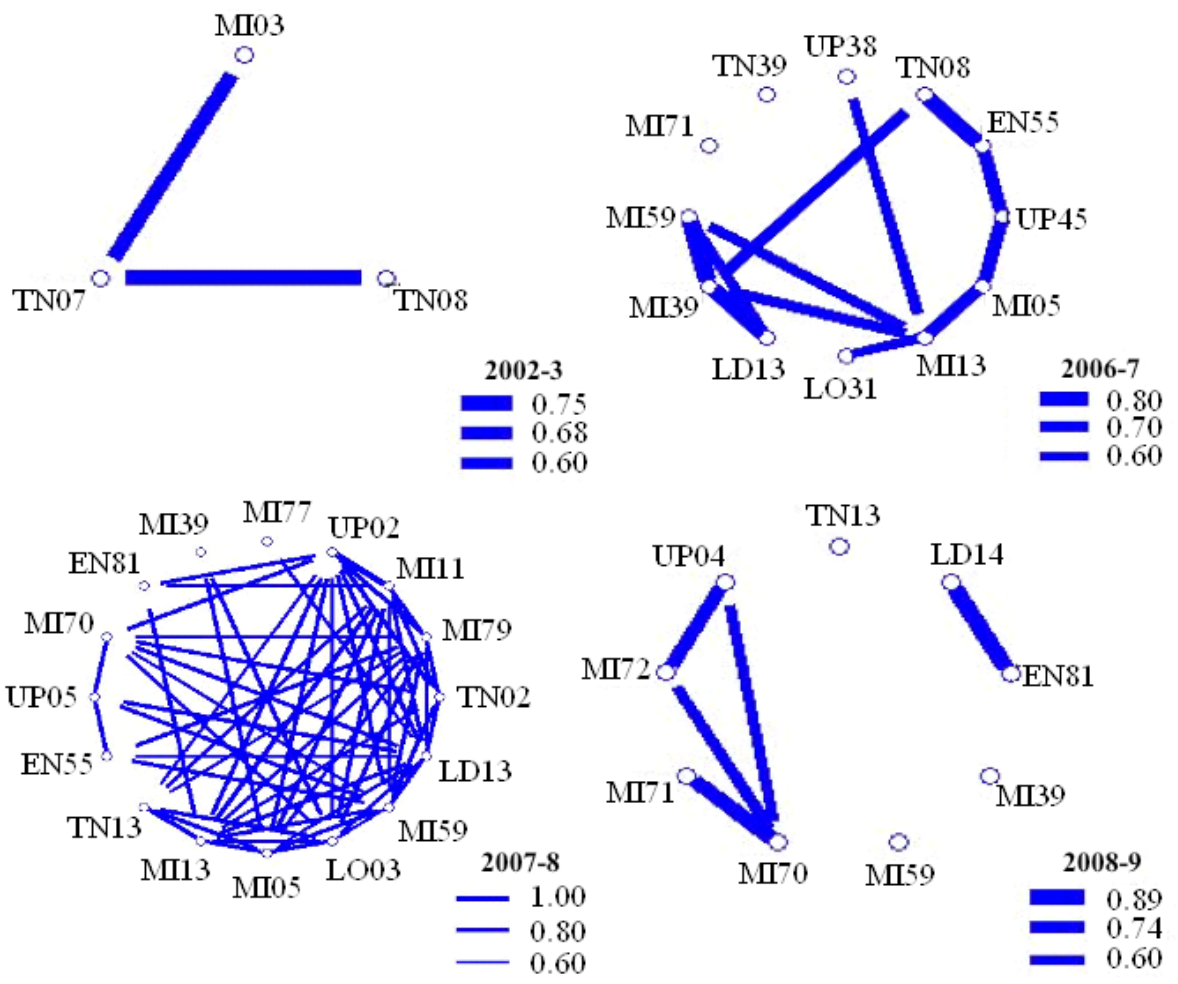

\section{Discussion}

Group size. Aggregations in animals are widely variable in size and composition, and their study is closely linked to the criteria used to define their limits (Shane et al. 1986; Wells et al. 1987; Shane 1990; Wells 1991; Smolker et al. 1992; Bejder et al. 1998; Whitehead 1999; Connor et al. 2000; Mareike 2003; Morteo 2011). The number of individuals in a group has been related to advantages while overcoming selective pressures, including but not limited to protection against harassment and predation, improving food acquisition and energy efficiency, thus leading to enhanced reproductive output (Wells et al. 1980; Shane et al. 1986; Mareike 2003).

Mean group size is often helpful to represent the optimal number of individuals for a community within a specific habitat (Würsig 1979), and the average group size found here (8.5 \pm 8.6 s.d.) was similar to other coastal locations across the Gulf of Mexico, the Caribbean and the Atlantic (Shane et al. 1986; Wells et al. 1987; Scott and Chivers 1990; Delgado 2002; García 1995; Morteo and Hernández 2007; Hernández-Candelario 2009; Martínez-Serrano et al. 2011). However, since the statistical distribution was skewed towards smaller aggregations (i. e. one third of the sightings were composed of solitary individuals and pairs) despite our inclusive definition (Figure 2), this value seems inconclusive. Morteo et al. (2014) anticipated this for bottlenose dolphins within the same study area, and determined that many of these small aggregations were likely single sexed. This strongly suggests that the community may be divided into small social units that join in common activities (Campbell et al. 2002).

Behavior. The general behavioral pattern suggested for most bottlenose dolphin communities is: Travelling > Socialization or Feeding > Resting > Evasion (Morteo 2002). Feeding has been reported as a common activity in many dolphin communities (Shane 1990; Bräger 1993; Morteo 
Figure 5. Proportion of non-random dyads by association (COA) and behavioral diversity (ADI) class in the study area during $2002-2009(n=237)$.

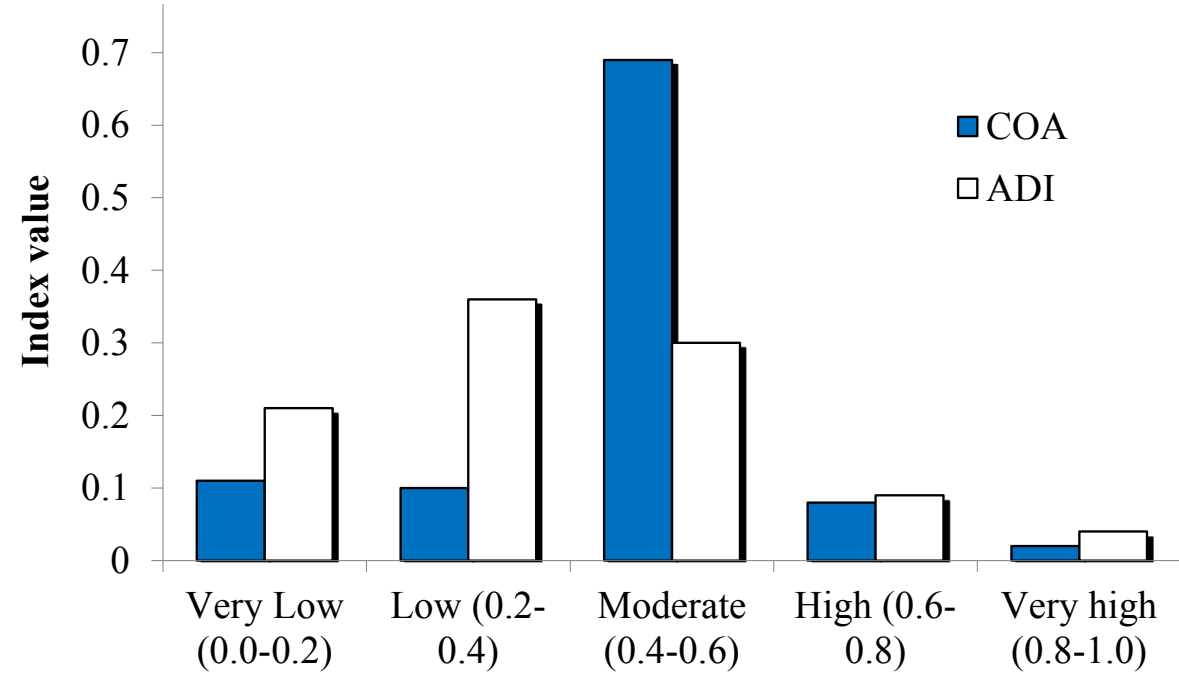

2002; Beddia 2007; Steiner 2011) and was the single most frequent activity (29\%) within the studied period, especially in the rainy months (15.5\%). Maze and Würsig (1999) hypothesized that dolphins may use environmental cues such as continental water runoffs to congregate over shallow coastal areas close to rivers and lagoons, taking advantage of increased prey populations; in fact, coastal bottlenose dolphins in this and in neighboring locations are known to experience seasonal expansions in their distribution during this time of the year (Martínez-Serrano et al. 2011; Medellín-Ortiz 2012). Although the latter may seem to enhance the possibilities of interacting with other dolphins in larger aggregations, Morteo (2011) suggested that as food seems abundant and predators are scarce in this study area, large groups might not necessarily imply an advantage for foraging or protection. The statistical distribution for group size is consistent with this hypothesis and it also explains the correspondence between the feeding records and the groups composed by 4 - 6 dolphins (Figure 3), thus strengthening the notion of a small-unit based social structure.

Following the same hypothesis, solitary individuals were significantly associated to evasive behavior (17\% of recorded sightings, Figure 3), which may be due to the frequent and antagonistic interactions between dolphins and artisanal fisheries using gillnets in this location. Resident

Figure 6. Mantel's correlation test $(r=0.98, P<0.01)$ between association coefficients $(C O A)$ and diversity of activities (ADI) for non-random dyads identified in the study area during $2002-2009(n=237)$. Half of the individual data was randomly removed.

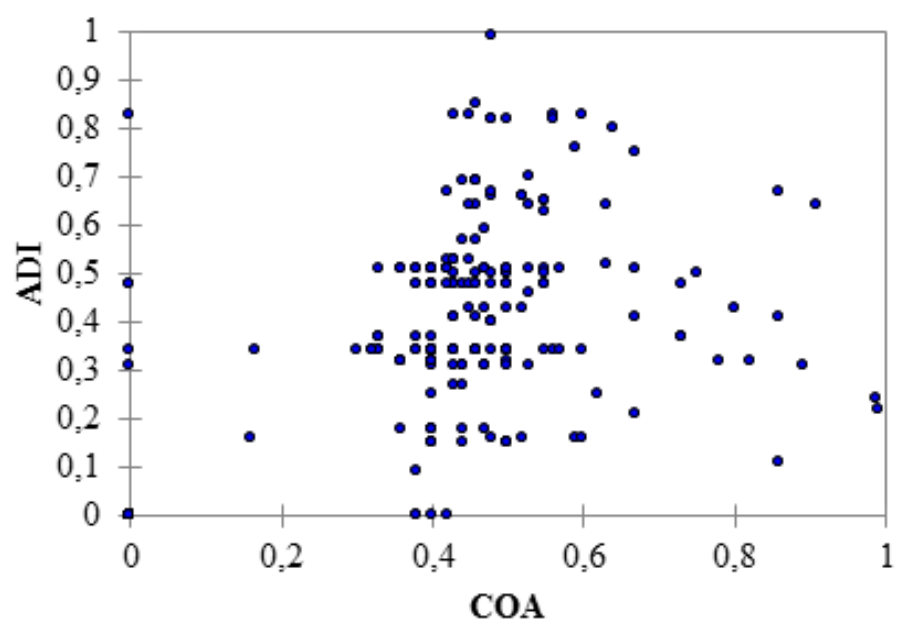


individuals face the inherent risk of being harassed, entangled or even killed, thus individuals rather than groups are more likely to evade detection by fishermen due to the extremely low visibility below the sea surface (Morteo et al. 2012). The latter also supports the argument that individuals in general gain larger benefits by aggregating in small groups (Figure 2) within this heavily fished area, and in extreme cases points to a "selfish strategy" as a mean for auto-preservation.

Habitat seasonality agreed with temporal differences found in both group size and behavior (Table 1; Del Castillo 2010; Martínez-Serrano et al. 2011; Morteo 2011; Medellín-Ortiz 2012); however, short-term habitat variability also seems to play an important role, since both of these variables were inconsistent throughout the studied period (Table 1). Morteo et al. (2012) pointed out the importance of boat traffic and fishing activities in the area, which seem to influence the presence and distribution of dolphins on a daily basis or even instantaneously (Constantine et al. 2004; Lusseau et al. 2006; Hernandez-Candelario 2009). Although many cetaceans seem to have habituated to certain levels of marine traffic, other evidence suggest that it may cause severe alterations in their behavior and in this case may promote the separation of group members, probably altering the social bonds within the community (Constantine et al. 2004; Morteo et al. 2012; Morteo et al. 2014).

Association patterns and behavioral diversity. A social organization is defined by the relations and interactions among individuals within the sampled population (Chapman et al. 1995). Societies are believed to gain from all the variety in their associations (Dunbar 1989); however, even in fission-fusion societies, partners could be selected to maximize efficiency or benefits while joining to develop their activities (Gero et al. 2005). In this study, up to $94 \%$ of all possible paired associations were non-significant, reaffirming the fluid nature of the community; however, $78 \%$ of the non-random pairs exhibited moderate to high membership (Figure 4). The congregation of prey within a limited area could help explain the random encounters for many of these dolphins (Morteo et al. 2012); on the other hand, the close associations for a small part of the community is likely the result of male alliances, and female bands (sensu Connor et al. 2000), by means of the sexual segregation occurring in the area (Morteo et al. 2014).

We found that dolphin interactions seem to modulate group size (Figure 2), and these are inherently associated to their own activities (Connor et al. 2001; Figure 3 and 5). The positive correlation between the level of association and the diversity of activities (Figure 6) was expected, as the context of the interactions between dyad members should become richer over time (Gero et al. 2005); however, the fact that 17 of the 237 significant dyads involved partnerships with specific purposes suggests that only a handful of these individuals find larger benefits from exploiting the specific abilities of selected partners. Lusseau et al. (2006) evidenced the importance of roles for specific individuals within a social network, where previous knowledge of group members and reduced number of participants helped to coordinate actions and facilitated cooperation; however such interactions were rare and deserve further attention.

Knowledge of the social structure of dolphin communities is important for assessing their ecological and evolutionary patterns; and behavioral data helps to understand how the animals adapt to the habitat and its selective pressures. However, both aspects are rarely combined to determine the nature of their associations, and how these are modified by their life conditions, including natural and anthropogenic factors. Human developments cause that coastal bottlenose dolphins face increasing disruptions within their core areas of distribution, therefore these aspects should be considered while developing and applying conservation and management strategies and policies. 


\title{
Acknowledgments
}

This research is part of the lead author's MSc thesis at the Universidad Veracruzana, Mexico, where she obtained fellowship from CONACyT. J. Montano, I. Hernández, V. Del Castillo and N. Medellín were involved in surveys and data collection. Fieldwork was carried with authorization from SEMARNAT permits SGPA/DGVS/00351/06 (E. Morteo) and SGPA/DGVS/00870/07, 02788/07, 01344/08 and 01649/08 (C. Bazúa). This work was supported by the following grants: PROMEP Apoyo a Nuevo PTC (E. Morteo) and CAMyCRA (E. Morteo, and H. Pérez-España), CONACyT grant 45468 (E. Velarde) and the Marine Mammal Laboratory of Universidad Veracruzana and Acuario de Veracruz, A.C.

\section{Resumen}

\begin{abstract}
Introducción: Las sociedades en mamíferos están influenciadas por factores intrínsecos y extrínsecos afectando la temporalidad de las asociaciones entre individuos. Los tursiones costeros generalmente viven en agregaciones pequeñas y fluidas de composición variable, pero comúnmente se desconoce la naturaleza de sus asociaciones. Nuestro objetivo fue determinar si el tamaño de grupo se relaciona con el comportamiento de los delfines y si los individuos se asocian para desarrollar actividades particulares en las costas de Alvarado, México.
\end{abstract}

Metodología: Se realizaron 80 navegaciones (2002 - 2003 y 2006 - 2009) para registrar la conducta, el tamaño de grupo y para foto-identificar a los delfines. De 237 avistamientos, con 2,021 delfines observados, se obtuvo un promedio de 8.5 (d. e. = 8.6) animales por grupo, donde las parejas y los individuos fueron más frecuentes (33\%).

Resultados: Las diferencias en tamaño de grupo y comportamiento concordaron con la estacionalidad del hábitat $(P<0.05)$, siendo inconsistentes entre años, por lo que los factores de corto plazo ( $i$ e. tránsito marino e intensidad de pesca) fueron importantes. La alimentación fue común (29\%) y correspondió con grupos de $4-6$ animales, mientras los individuos solitarios típicamente mostraron evasión $(P<0.01)$.

Discusión y conclusiones: Los coeficientes de asociación calculados para 89 de 232 delfines identificables fueron no aleatorios en sólo $6 \%$ de las 3,915 combinaciones $(P<0.05)$; dichos valores se correlacionaron positivamente con la diversidad de actividades de cada pareja $(P<0.01)$ y la naturaleza de sus asociaciones se volvió más rica con el tiempo en el $93 \%$ de los casos. Se cree que esta comunidad se compone de pequeñas unidades que intercambian miembros; esto puede deberse a una alta abundancia de alimento y bajo número de depredadores en el área, pero también a una estrategia para evitar la detección y las amenazas derivadas de la pesca artesanal.

Palabras clave: Comportamiento; evasión; membresía; pesquerías; socialización; tamaño de grupo.

\section{References}

Altmann, J. 1974. Observational study of behavior sampling methods. Behaviour 49:227-67.

BedDIA, L. 2007. Diurnal behaviour of bottlenose dolphins (Tursiops truncatus) in the Cardigan Bay, West Wales. Doctoral thesis. School of Biological Science, University of Wales. Bangor, United Kindom.

BeJder, L., D. Fletcher, AND S. BRÄger. 1998. A method for testing association patterns of social animals. Animal Behavior 56:719-725.

BRÄGER, S. 1993. Diurnal seasonal behavior patterns of bottlenose dolphins (Tursiops truncatus). Marine Mammal Science 9:434-438.

Bräger, S., B. Würsig, A. Acevedo, And T. Henningsen. 1994. Association patterns of Bottlenose dolphins (Tursiops truncatus) in Galveston Bay, Texas. Journal of Mammalogy 75:431-437.

Campbell, G. S., B. A. Bilgre, and R. H. Defran. 2002. Bottlenose dolphins (Tursiops truncatus) in Turneffe Atoll, Belize: Ocurrence, site fidelity, group size and abundance. Aquatic Mammals 28:170-180.

Chapman, C. A., R. W. Wrangham, And L. J. Chapman. 1995. Ecological constraints on group size: an analysis of spider monkey and chimpanzee subgroups. Behavioral Ecology and Sociobiology 36:59-70.

Chilvers, B. L., And P. J. Corkeron. 2002. Association patterns of bottlenose dolphins (Tursiops truncatus) 
off Point Lookout. Queensland. Australia. Canadian Journal of Zoology 80:973-979.

Connor, R. C., R. A. Smolker, And A. F. Richards. 1992. Dolphin alliances and coalitions. Pp. 415-443 in Coalitions and alliances in humans and other animals (Harcourt A. H., and F. B. M. de Waal, eds.). Oxford University Press. Oxford, United Kindom.

Connor, R. C., R. S. Wells, J. Mann, and A. Read. 2000. The Bottlenose dolphin. Pp. 91-126 in Cetacean societies (Mann, J., R. C. Connor, P. Tyack, and H. Whitehead, eds.). The University of Chicago Press. Chicago, EE. UU.

Connor, R. C., M. R. Heithaus, And L. M. Barre. 2001. Complex social structure, alliance stability and mating access in bottlenose dolphin 'super-alliance'. Proceedings of the Royal Society of London B 268:263-267.

Constantine, R., D. H. Brunton and T. Dennis. 2004. Dolphin-watching tour boats change bottlenose dolphin (Tursiops truncatus) behaviour. Biological Conservation 117:199-307.

Del Castillo, V. 2010. Ecología poblacional del tursión (Tursiops truncatus) en la costa de Alvarado, Veracruz. Undergraduate thesis. Benemérita Universidad Autónoma de Puebla. Puebla, México.

Delgado, A. 2002. Comparación de parámetros poblacionales de las toninas, Tursiops truncatus, en la región sureste del Golfo de México (Estados de Tabasco, Campeche, Yucatán y Quintana Roo). Doctoral thesis. Facultad de Ciencias, Universidad Nacional Autónoma de México. Ciudad de México, México.

Dunbar, R. I. M. 1989. Social systems as optimal strategy sets: the costs and benefits of sociality. Pp. 131-149 in Comparative socioecology: The behavioral ecology of humans and other mammals (Standen V., and R. A. Foley, eds.). Blackwell Scientific Publications. Oxford, United Kindom.

Fazioli, K. L., S. Hofmann, and R. S. Wells. 2006. Use of Gulf of Mexico coastal waters by distinct assemblages of bottlenose dolphins (Tursiops truncatus). Aquatic Mammals 32:212-222.

FÉLIX, F. 1997. Organization and social structure of the coastal bottlenose dolphins Tursiops truncatus in the Gulf de Guayaquil, Ecuador. Aquatic Mammals 23:1-16.

García, R. 1995. Presencia de toninas, Tursiops truncatus (Montagu 1821), en la Zona de pesca de camarón de Alvarado, Ver. México (Cetácea: Delphinidae). Undergraduate thesis. Facultad de Biología. Universidad Nacional Autónoma de México. Iztacala, México.

García-Vital, M. 2012. Relación de los patrones de asociación y las actividades de delfines (Tursiops truncatus) residentes de Alvarado, Veracruz. MSc thesis. Instituto de Ciencias Marinas y Pesquerías, Universidad Veracruzana. Boca del Río, Mexico.

Gero, S., L. Bejder, H. Whitehead, J. Mann, And R. C. Connor. 2005. Behaviourally specific preferred associations in bottlenose dolphins, Tursiops spp. Canadian Journal of Zoology 83:1566-1573.

Goodall, J. 1986. The chimpanzees of Gombe: Patterns of behavior. The Belknap Press of the Harvard University Press. Cambridge, EE. UU.

Hernández-Candelario, I. C. 2009. Interacción del delfín costero Tursiops truncatus con embarcaciones y artes de pesca en el Sistema Arrecifal Veracruzano. MSc thesis. Centro de Investigación Científica y de Educación Superior de Ensenada. Ensenada, Mexico.

Hurlbert, S. H. 1984. Pseudoreplication and the design of ecological field experiments. Ecological Monographs 54:187-211

lusseau, D., B. Wilson, P. S. Hammond, K. Greller, J. W. Durban, K. M. Parsons, T. R. Barton, and P. M. Thompson. 2006. Quantifying the influence of sociality on population structure in bottlenose dolphins. Journal of Animal Ecology 75:14-24.

MaChlis, L., P. W. D. Dood, AND J. C. Fentress. 1985. The pooling fallacy: Problems arising when individuals contribute more than one observation to the data set. Zeitschrift für Tierpsychologie 68:201-14.

Mareike, S. E. 2003. The social affiliation and group composition of bottlenose dolphins (Tursiops truncatus) in the outer southern Moray Firth, NE Scotland. MSc thesis. School of Biological Science. University of Whales. Whales, United Kindom. 
Martínez-Serrano, I., A. Serrano, G. Heckel, and Y. Schramm. 2011. Distribución y ámbito hogareño de toninas (Tursiops truncatus) en Veracruz, México. Ciencias Marinas 37:379-392.

Maze, K. S., AND B. Würsıg. 1999. Bottlenose dolphins of San Luis Pass, Texas: Ocurrence patterns site fidelity, and habitat use. Aquatic Mammals 25:91-103.

McDonald, D. W., And G. M. CarR. 1989. Food security and the rewards of tolerance. Pp. 75-99 in Comparative socioecology: The behavioural ecology of humans and other mammals (Standenana V., and R.A. Foley, eds.). Blackwell Scientific Publications. Oxford, United Kindom.

Medellín-Ortiz, B. N. 2012. Diferencias sexo-específicas en las áreas núcleo de la distribución de los delfines Tursiops truncatus frente al sistema lagunar de Alvarado, Golfo de México. MSc thesis. Instituto de Ciencias Marinas y Pesquerías, Universidad Veracruzana. Boca del Río, México.

Morteo, E. 2002. Distribución y movimientos del tursión (Tursiops truncatus: Montagu, 1821) en las aguas adyacentes a San Quintín, Baja California, México (Cetacea: Delphinidae). Undergraduate thesis. Universidad Autónoma de Baja California. Ensenada, México.

Morteo, E. 2011. Ecología social de los delfines (Tursiops truncatus) en las aguas costeras de Alvarado, Veracruz, México. Doctoral thesis. Instituto de Ciencias Marinas y Pesquerías. Universidad Veracruzana. Boca del Río, México.

Morteo, E., And I. Hernández. 2007. Resultados preliminares sobre la relación entre delfines Tursiops truncatus, embarcaciones y artes de pesca en el Sistema Arrecifal Veracruzano. Pp. 241-256 in Investigaciones Científicas en el Sistema Arrecifal Veracruzano (Granados-Barba, A., L. G. AbarcaArenas, y J. M. Vargas-Hernández (eds.). Promep, Universidad Veracruzana, Universidad Autónoma de Campeche. Campeche, México.

Morteo E., A. Rocha-Olivares, P. Arceo-Briseño, and L. G Abarca-Arenas. 2012. Spatial analyses of bottlenose dolphin-fisheries interactions reveal human avoidance off a productive lagoon in the western Gulf of Mexico. Journal of the Marine Biological Association of the United Kingdom 92:1893-1900.

Morteo E., A. Rocha-Olivares, and L. G. Abarca-Arenas. 2014. Sexual segregation in coastal bottlenose dolphins (Tursiops truncatus) in the south-western Gulf of Mexico. Aquatic Mammals 40:375-385.

Quintana-Rızzo, P. 2006. Group fission-fussion dynamics and communication in the bottlenose dolphin (Tursiops truncatus). MSc thesis. Graduate School Theses and Dissertations. University of South Florida. Tampa, USA.

QuintanA-Rızzo, E., AND R. S. Wells. 2001. Resighting and association patterns of bottlenose dolphins (Tursiops truncatus) in the Cedar Keys, Florida: insights into social organization. Canadian Journal of Zoology 79:447-456.

Rogers, C. A., B. J. Brunnick, D. L. Herzing, ANd J. D. Baldwin. 2004. The social structure of bottlenose dolphins, Tursiops truncatus, in the Bahamas. Marine Mammal Science 20:688-708.

Roughgarden, J. 1989. The structure and assembly of communities. Pp. 203-226 in Perspective in ecological theory (Roughgarden, J., R. M. May, y S. A. Levin, eds). Princeton University Press. Princeton, EE. UU.

Scott, M. D., And S. J. Chivers. 1990. Distribution and herd structure of bottlenose dolphins in the eastern tropical Pacific Ocean. Pp. 387-402 in The bottlenose dolphin (Leatherwood, S., and R. R. Reeves, eds.). Academic Press. San Diego, EE. UU.

Shane, S. H. 1990. Behavior and ecology of the bottlenose dolphin at Sanibel island, Florida. Pp. 245-265 in The bottlenose dolphin (Leatherwood, S., and R. R. Reeves, eds.). Academic Press Inc. San Diego, EE. UU.

Shane, S. H., R. S. Wells, ANd B. Würsıg. 1986. Ecology, behavior and social organization of the Bottlenose Dolphin: A review. Marine Mammal Science 2:34-63.

Smolker, R. A., A. F. Richards, R. C. Connor, And J. W. Pepper. 1992. Sex differences in patterns association among Indian Ocean bottlenose dolphins. Behavior 123:38-69. 
Steiner, A. 2011. Activity budget of inshore Indo-pacific bottlenose dolphin (Tursiops aduncus): A critical evaluation of methods and comparison among other populations. Marine Mammal Science 271:20-38.

WeLLS, R. S. 1991. The role of long-term study in understanding the social structure of a bottlenose dolphin community. Pp. 199-226 in Dolphins societies (Pryor, K., and K. Norris, eds.). University of California Press. Los Angeles, EE. UU.

Wells, R. S., A. B. IRvine, ANd M. D. Scott. 1980. The social ecology of inshore Odontocetes. Pp 263-317 in Cetacean behavior: mechanisms and functions (Hermann, L.M. ed.). John Wiley y Sons. Nueva York, EE. UU.

Wells, R. S., M. D. Scott, ANd A. B. IRvine. 1987. The social structure of free-ranging bottlenose dolphins. Pp. 247-305 in Current mammalogy (Genoways H. H. ed.). Plenum Press. New York, EE. UU.

WhiteheAd, H. 1999. Testing association patterns of social animals. Animal Behaviour 57:F26-29

WhITEHEAD, H. 2009. SOCPROG programs: analyzing animal social structures. Behavioral Ecology and Sociobiology 63:765-778.

Whitehead, H., R. Antunes, S. Gero, S. N. Wong, D. Engelhaupt, and L. Rendell. 2012. Multilevel societies of female sperm whales (Physeter macrocephalus) in the Atlantic and Pacific: why are they so different? International Journal of Primatology 33:1142-1164.

Wrangham, R. W., R. Gittleman, and C. A. Chapman. 1993. Constraints on group size in primates and carnivores: population density and day-range as assays of exploitation competition. Behavioral Ecology and Sociobiology 32:199-210.

WürSIG, B. 1979. Dolphins. Scientific American 240:136-48.

Würsig, B., AND T. A. Jefferson. 1990. Methods of photo-identification for small cetaceans. Report International Whaling Commission 12:43-52.

Summited: February 13, 2015

Review: April 8, 2015

Accepted: April 21, 2015

Associated editor: Juan Pablo Gallo 
350 THERYA Vol.6(2):337-350 